\title{
PENGARUH PARTISIPASI PENYUSUNAN ANGGARAN TERHADAP KINERJA APARAT PEMERINTAH DAERAH \\ (Studi Kasus Pada Dinas Pendapatan, Pengelolaan Keuangan Aset Daerah Kota Palopo)
}

\author{
Suhardi M Anwar ${ }^{1}$ \\ Sumiati ${ }^{2}$
}

No. HP $081343513111^{1}$

\begin{abstract}
ABSTRAK
Tujuan dari penelitian ini adalah seberapa besar pengaruh Partisipasi Penyusunan Anggaran Terahadap Kinerja Aparat Pemerintah Daerah Pada DPPKAD. Metode analisis data yang digunakan adalah metode analisis regresi linier sederhana yaitu dengan rumus $Y=a+B x$ menggunakan SPSS Versi 21. Adapun metode dalam penentuan $t$ table menggunakan ketentuan tingkat signifikan $5 \%$ df dengan $d f=n-k$.

Penelitian ini dilaksanakan pada DPPKAD Kota Palopo. Variabel independen adalah Pengaruh Partisipasi Penyusunan Anggaran. sedangkan variabel dependen adalah Kinerja Aparat Pemerintah Daerah. Data dalam penelitian ini merupakan data primer dengan menyebarkan kuesioner.
\end{abstract}

Secara parsial, Hasil penelitian ini menunjukkan bahwa variabel partisipasi penyusunan anggaran berpengaruh signifikan terhadap kinerja aparat pemerintah daerah . hasil uji $t$ menunjukkan bahwa secara parsial variabel independen partisipasi penyusunan anggaran berpengaruh signifikan terhadap kinerja aparat pemerintah daerah. Hal ini dapat dilihat pada nilai signifikansi sebesar $t$ hitung (4.041) $>t$ table $(1,860)$ dan signifikansi penelitian lebih kecil dari $0,05(0,819>0,05)$.

Kata Kunci: Partisipasi Penyusunan Anggaran, Kinerja Aparat Pemerintah
Daerah

\section{PENDAHULUAN}

Sebagai organisasi sektor publik, pemerintah daerah dituntut agar memiliki kinerja yang berorientasi pada kepentingan masyarakat, dan mendorong pemerintah untuk senantiasa tanggap akan tuntutan lingkungannya, dengan upaya memberikan pelayanan terbaik secara transparan dan berkualitas serta pembagian tugas, Kinerja instansi pemerintah banyak mendapat sorotan karena sering memonitor setiap perencanaan pemerintah dalam satu periode.

$$
\text { Partisipasi dalam penyusunan }
$$

anggaran menciptakan kesempatan pada bawahan untuk terlibat dan mempengaruhi proses penyusunan anggaran. Dalam peningkatan komitmen terdapat upaya yang sungguh-sungguh untuk melaksanakan dan mendapat target anggaran yang telah disepakati bersama.

Sesuai dengan PP nomor 71 Tahun 2010, Penerapan SAP berbasis akrual dapat dilaksanakan secara bertahap. Pemerintah dapat menerapkan SAP berbasis kas menuju akrual paling lambat Tahun anggaran 2015. Selain mengatur SAP berbasis akrual PP nomor 71 tahun 2010 juga mengatur juga mengatur SAP berbasis kas menuju Akrual yang saat ini masih digunakan oleh seluruh entitas.

Proses penganggaran daerah diatur dalam Kepmendagri Nomor 13 tahun 2006. Regulasi tersebut menjelaskan tentang 
pedoman dalam ran cangan anggaran pendapatan dan belanja daerah (APBD) yang dilaksanakan oleh tim anggaran eksekutif bersama-sama unit organisasi perangkat daerah (unit kerja). Rancangan anggaran unit kerja dimuat dalam suatu dokumen yang disebut Rancangan Anggaran Satuan Kerja (RASK). RASK memuat standar analisis belanja, tolak ukur kinerja dan standar biaya sebagai instrumen pokok dalam anggaran kinerja.

Anggaran pada sektor pemerintahan terkait dengan proses penentuan jumlah alokasi dana di setiap program dan aktivitas, pada anggaran sektor publik anggaran yang telah disusun dipublikasikan kepada rakyat, dimana anggaran dari sektor publik berasal dari pajak, retribusi, laba perusahaan milik daerah atau negara, pinjaman pemerintah berupa utang luar negri dan obligasi. Sedangkan dalam sektor swasta anggaran yang telah disusun tidak akan dipublikasikan kepada rakyat karena anggaran tersebut bersifat rahasia. Dana anggaran dari sektor swasta berasal dari modal sendiri, laba ditahan, aktiva, dan pembiayaan eksternal yang meliputi: utang bank, obligasi, penerbitan saham.

Adapun faktor-faktor yang dapat mempengaruhi kinerja adalah komitmen organisasi, budaya organisasi, akuntabilitas, kepuasan kerja dan kepemimpinan. Komitmen organisasi adalah komitmen yang diciptakan oleh semua komponen-komponen individual dalam menjalankan operasional organisasi. Tinggi rendahnya komitmen pegawai terhadap organisasi tempat mereka bekerja sangat menentukan untuk pencapaian dalam oraganisasi.

Masalah-masalah yang berkaitan dengan hubungan partisipasi penyusunan anggaran dan kinerja manajerial aparatur pemerintah merupakan masalah yang banyak diperdebatkan, buktiempiris memberikan hasil yang bervariasi dan tidak konsisten. Penelitian yang dilakukan oleh Yulia (2008) yang melakukan penelitian pada SKPD pemerintahan kota Padang. Hasil penelitian tersebut menunjukkan bahwa partisipasi penganggaran berpengaruh signifikan positif terhadap kinerja aparatur pemerintah daerah. Sedangkan budaya organisasi dan komitmen organisasi tidak mempengaruhi hubungan partisipasi anggaran terhadap kinerja aparat.

Namun, berbeda denga penelitian yang dilakukan oleh Milani (1975) dalam Mediaty (2010), melakukan penelitian terhadap proses penyusunan anggaran pada sebuah perusahaan besar yang berskala internasional di mana hasil penelitian tersebut adalah ditemukannya hubungan yang tidak signifikan antara partisipasi dalam penyusunan anggaran dan kinerja manajerial.

Adapun hasil penelitian Sumarno (2005) juga menyebutkan bahwa terdapat pengaruh dan hubungan negatif yang kuat antara partisipasi penyusunan anggaran dengan kinerja manajerial. Hasil tersebut tidak konsisten dengan hasil penelitian Nor (2007) menyebutkan adanya pengaruh positif signifikan antara partisipasi penyusunan 
anggaran dengan kinerja manajerial pada sektor publik.

Penelitian yang dilakukan Siskawati (2004) mendapat hasil bahwa partisipsi penyusunan anggaran berpengaruh terhadap kinerja Pemerintah daerah. Selanjutnya (Sardjito, 2007) melakukan penelitian tentang partisipasi penyusunan anggaran dengan kinerja Aparat Pemerintah Daerah dan menunjukkan bahwa adanya pengaruh yang signifikan antara partisipasi penyusunan anggaran dengan kinerja aparat pemerintah daerah, dan menyebutkan bahwa semakin tinggi partisipasi anggaran maka semakin meningkat kinerja aparat pemerintah daerah.

\section{METODE PENELITIAN}

penelitian ini dilaksanakan pada DPPKAD Kota Palopo. Jenis data yang digunakan yaitu data kuantitatif. data kuantitatif dan sumber data yang digunakan yaitu primer yang diperoleh dari hasil observasi, wawancara, dan kuesioner dengan pihak yang berhubungan langsung dengan proses penyusunan anggaran di DPPKAD Kota Palopo. Populasi pada penelitian ini adalah Aparatur Pemerintah/ Pegawai yang terlibat dalam penelitian penyusunan APBD, yang hanya berjumlah 10 orang pegawai yang berpartisipasi. Sehingga populasi dalam penelitian ini sekaligus merupakan sampel penelitian.

\section{Metode Analisis Data}

Analisis data yang digunakan dalam penelitian ini adalah analisis regresi sederhana. Penulis mengemukakan rumus analisis regresi sederhana sebagai berikut:

$$
\begin{array}{rlrl} 
& \mathrm{Y} & =\mathrm{a}+\mathrm{bX} \\
& \text { Keterangan: } \\
\mathrm{Y} & = & \text { Kinerja Aparatur Pemerintah } \\
\mathrm{a} & =\text { Konstanta } \\
\mathrm{b} & =\text { Koefisien Regresi } \\
\mathrm{X} & =\text { Partisipasi Penyusunan Anggaran }
\end{array}
$$

\section{HASIL PENELITIAN DAN PEMBAHASAN}

\section{Pembahasan}

\section{Kinerja pegawai DPPKAD}

Hasil wawancara terhadap kepala bidang anggaran di lokasi penelitian tentang kinerja instansi pemerintah Dinas Pendapatan, Pengelolaan Keuangan, dan Aset Daerah menyatakan bahwa laporan akuntabilitas kinerja instansi pemerintah (LAKIP) Dinas Pendapatan, Pengelolaan Keuangan dan Aset DaerahTahun 2013 merupakan bentuk pertanggung jawaban pelaksanaan kegiatan selama kurun waktu Januari sampai Desember 2013. LAKIP ini dimaksudkan untuk menindaklanjuti Instruksi Presidan RI Nomor 7 Tahun 1999 tentang Akuntabilitas Kinerja Instansi Pemerintah.

1. Mengacu pada rencana strategi 20082013 Dinas Pendapatan Pengelolaan Keuangan dan Aset Daerah:

a. Sasaran strategi Dinas pendapatan Pengelolaan Keuangan dan Aset Daerah adalah:

- Meningkatkan kualitas sumber daya manusia aparat

- Meningkatnya pelayanan 
- Keterlibatan masyarakat dan stekholder dalam peningkatan sumber-sumber pendapatan asli daerah

- Terjaganya kualitas sistim dan manajemen pengelolaan kuanagan aset daerah

- Meningkatnya pemanfaatan informasi pelaporan pendapatan, keuangan dan aset daerah.

b. Indikator kinerja utana Dinas Pendapatan, Pengelolaan Keuangan dan Aset Daerah Tahun 2013 adalah:

- Konstribusi Pendapatan Asli Daerah sebesar $7,50 \%$

- Realisasi pelaksanaan APBD sebesar $100 \%$

- Penyediaan sistim dan Manajemen Keuangan dan Aset Daerah sebanyak 41 SKPD

- Pemanfaatan informasi pengelolaan keuangan daerah sebanyak 15 kali

2. Mengacu pada realisasi indikator kinerja utama Dinas Pendapatan, Pengelolaan Keuangan dan Aset Daerah berdasarkan pada realisasi kinerja Tahun anggaran 2013, dapat disampaikan bahwa:

a. Pencapaian Dinas Pendapatan, pengelolaan Keuangan dan Aset Daerah yang berhubungan dengan persentase konstribusi pendapatan asli daerah terhadap pendapatan daerah (IKU 1) adalah sebesar 114\% artinya Dinas Pendapatan, Pengelolaan Keuangan dan Aset
Daerah melampaui target yang telah ditetapkan.

b. Pencapaian Dinas sumber pendapatan, pengelolaan keuangan dan aset daerah yang berhubungan dengan persentase realisasi pelaksanaan APBD Indikator kinerja utama (IKU 2) adalah sebesar 96,82\% artinya Dinas Pendapatan, pengelolaan Keuangan dan Aset Daerah belum berhasil mencapai target yang telah ditetapkan.

c. Pencapaian Dinas Pendapatan, pengelolaan Keuangan dan Aset Daerah yang berhubungan dengan penilaian Laporan Keuangan SKPD terhadap Entitas pelaporan (IKU 3) adalah wajar tanpa pengecualian (WTP), yang artinya Dinas Pendapatan, Pengelolaan Keuangan dan Aset Daerah berhasil memenuhi target yang telah ditetapkan

d. Pencapaian dinas Pendapatan, Pengelolaan keuangan dan Aset Daerah yang berhubungan dengan penyediaan sistem informasi manajemen keuangan dan aset daerah yang telah digunakan (IKU 4) adalah sebesar 90,24\% yang artinya Dinas Pendapatan, Pengelolaan Keuangan dan Aset Daerah belum dapat merealisasikan target yang ditetapkan.

e. Pencapaian Dinas Pendapatan, Pengelolaan Keuangan dan Aset Daerah yang berhubungan dengan 
pemanfaatan informasi pengelolaan keuangan dan Aset Daerah (IKU 5) adalah sebanyak $77,33 \%$ yang artinya Dinas Pendapatan, Pengelolaan Keuangan dan Aset Daerah belum dapat mencapai target yang telah ditetapkan

3. Mengacu pada realisasi sasaran strategi Dinas pendapatan, Pengelolaan Keuangan dan Aset Daerahberdasarkan pada realisasi kinerja tahun anggaran 2013, dapat disampaikan bahwa:

\section{a. Pencapaian Dinas sumber} Pendapatan, Pengelolaan keuangan dan Aset Daerah yang berhubungan dengan sasaran strategi 1 (meningkatnya kualitas sumber daya informasi pelaporan dapat diakses masyarakat dan stekholder dengan membandingkan antara jumlah layanan informasi yang dapat digunakan dengan penggunaan layanan informasi dimaksud dengan total pencapaian adalah sebesar $73,33 \%$ yang artinya Dinas Pendapatan, pengelolaan Keuangan dan Aset Daerah belum berhasil mencapai target yang telah ditetapkan dalam sasaran strateginya.

4. Berdasarkan uraian diatas, dapat disimpulkan bahwa Dinas Pendapatan, Pengelolaan Keuangan dan Aset Daerah secara umum dapat secara optimal memenuhi target kinerja yang ada dalam indikator kinerja utama atau hanya sebesar $94,59 \%$ dan pada pencapaian sasaran strategi yang terdapat dalam dokumen rencana strategi 2008-2013, Dinas Pendapatan, Pengelolaan Keuangan dan Aset Daerah hanya sebesar 96,31\%. Meskipun demikian, dari hasil evaluasi pengukuran kinerja yang memuat perbandingan antara hasil kerja aktual dengan tujuan/ sasaran kinerja, maka tingkat keberhasilan pelaksanaan kinerja Dinas pendapatan, pengelolaan Keuangan dan Aset Daerah untuk pencapaian indikator kinerja utama 86\%-100\% maupun dalam pencapaian target sasaran strategis berada pada skala ukur antara 86\%-100\% atau dengan kriteria sangat baik atau sangat berhasil

5. Kendala-kendala yang dihadapi dalam pelaksanaan program atau kegiatan selama tahun 2013 adalah:

a. Ketersediaan sumber daya manusia aparat yang memiliki latar belakang pendidikan teknis (akuntansi) masi sangat terbatas.

b. Forum pelaksanaan koordinasi dan konsultasi antar SKPD dan lintas instansi belum dilaksanakan secara rutin dan berkala.

c. Aturan hukum yang belum lengkap, termasuk didalamnya pedoman pelaksanaan pengelolaan pendapatan keuangan, dan aset daerah sebagai turunan dari aturan perundangan diatasnya.

6. Berkenaan dengan kendala tersebut di atas, strategi yang diambil oleh Dinas 
Pendapatan, Keunagan dan Aset Daerah adalah:

a. Penambahan sumberdaya manusia aparat melalui pemenuhan kebutuhan personil yang memiliki keahlian tertentu

b. Peningkatan kerja sama dengan SKPD dan instansi vertikal (Kota Palopo. Provinsi, dan Kementrian terkait) dalam pelaksanaan program/ kegiatan.

c. Penyediaan tata aturan yang terkait pelaksanaan secara teknis pada Dinas Pendapatan, Pengelolaan Keuangan dan Aset Daerah.

secara umum belum dapat secara optimal memenuhi target kinerja yang ada dalam Indikatot Kinerja Utama atau hanya sebesar 94,59\% dan pada pencapaian sasaran strategis yang terdapat dalam dokumen rencana strategis 2008-2013, Dinas Pendapatan, Pengelolaan Keuangan dan Aset Daerah hanya sebesar 96,31\%. Meskipun demikian, dari hasil evaluasi pengukuran kinerja yang memuat perbandingan antara hasil kerja aktual dengan tujuan/sasaran kinerja, maka tingkat keberhasilan pelaksanakan kinerja Dinas Pendapatan, Pengelolaan Keuangan dan Aset Daerah untuk pencapaian indikator kerja utama $86 \%-100 \%$ maupun dalam hal pencapaian target sasaran strategi berada pada skala ukur antara $86 \%-100 \%$ atau dengan kriteria sangat baik dan sangat berhasil.

\section{Pengujian Hipotesis}

Untuk menguji bahwa pengaruh partisipasi penyusunan anggaran terhadap kinerja aparat pemerintah daerah maka pengujian hipotesis dilakukan dengan menggunakan uji $t$

a. Pengujian Hipotesis dengan Uji $t$

Dalam pengujian hipotesis dengan memperhatikan nilai $t$ hitung dari hasil regresi tersebut untuk mengetahui pengaruh variabel independen secara parsial terhadap variabel dependen dengan tingkat kepercayaan $95 \%$ atau pada alpha $5 \%$. Dengan syarat apabila nilai variabel independen signifikan terhadap variabel dependen maka terdapat pengaruh independen terhadap variabel dependen, sedangkan apabila tidak signifikan maka tidak terdapat pengaruh antara variabel independen terhadap variabel dependen.

Pada penelitian uji t digunakan untuk menguji apakah hipotesis yang diajukan dalam penelitian ini diterima atau tidak dengan mengetahui apakah variabel independen secara parsial mempengaruhi variabel dependen. 
Adapun metode dalam penentuan

t tabel menggunakan ketentuan tingkat

signifikan $5 \%$ dengan $\mathrm{df}=\mathrm{n}-\mathrm{k}($ dalam penelitian ini $\mathrm{df}=10-2=8$ ), sehingga didapat nilai $t$ tabel sebesar 1,860 disajikan dalam table sebagai berikut:

Tabel 1

Hasil Uji t coefficients ${ }^{a}$

\begin{tabular}{|l|c|l|l|l|}
\hline \multicolumn{1}{|c|}{ Variabel } & Standardized Coefficients (Beta) & $\mathrm{t}_{\text {hitung }}$ & $\mathrm{t}_{\text {tabel }}$ & Sig. \\
\hline $\begin{array}{l}\text { Partisipasi Penyusunan } \\
\text { Anggaran }\end{array}$ & 0,819 & 4,041 & 1,860 & 0,004 \\
\hline
\end{tabular}

\section{Sumber: Data Primer 2014}

Dari tabel 1 di atas diketahui nilai $\mathrm{t}$ hitung sebesar 4,041> $\mathrm{t}$ tabel sebesar 1,860 sehingga $\mathrm{H}_{0}$ ditolak dan $\mathrm{H}_{1}$ diterima. Artinya bahwa dengan kisaran sebesar 0,819 atau $81,9 \%$, hubungan linear antara partisipasi penyusunan anggaran terhadap kinerja aparat DPPKAD signifikan.

\section{Hasil Persamaan Regresi}

Dari hasil uji SPSS Versi.21, maka diperoleh persamaan regresi sederhana sebagai berikut:

$Y=0,361+0,819 X$

Model tersebut dapat diinterprestasikan sebagai berikut:

Tabel 2

Hasil Persamaan Regresi Coefficients ${ }^{a}$

\begin{tabular}{|c|c|c|c|c|c|c|}
\hline \multirow{2}{*}{\multicolumn{2}{|c|}{ Model }} & \multicolumn{2}{|c|}{$\begin{array}{l}\text { Unstandardized } \\
\text { Coefficients }\end{array}$} & \multirow{2}{*}{$\begin{array}{c}\begin{array}{c}\text { Standardize } \\
\mathrm{d} \\
\text { Coefficients }\end{array} \\
\text { Beta }\end{array}$} & \multirow[t]{2}{*}{$\mathrm{t}$} & \multirow[t]{2}{*}{ Sig. } \\
\hline & & $B$ & $\begin{array}{l}\text { Std. } \\
\text { Error }\end{array}$ & & & \\
\hline & (Constant) & .361 & .724 & & .499 & .631 \\
\hline 1 & $\begin{array}{l}\text { Partisipasi } \\
\text { Penyusunan } \\
\text { Anggaran }\end{array}$ & .788 & .195 & .819 & 4.041 & .004 \\
\hline
\end{tabular}

a. Dependent Variable: Kinerja Pemerintah Daerah

Sumber Data: Hasil Pengolahan SPPS (2014) 
Dengan menggunakan regresi sederhana maka diperoleh nilai koefisien variabel independen variabel berpengaruh sebesar 0,819 dapat diartikan jika variabel bebas dengan model diasumsikan sama dengan nol, maka rata-rata variabel diluar model tetap akan meningkatkan kinerja aparat pemerintah daerah sebesar 0,81,9\% (satuan).

Persamaan regresi tersebut di atas menunjukkan adanya pengaruh positif antara variabel dependen kinerja aparat pemerintah daerah. terhadap variabel independen partisipasi penyusunan anggaran.
Model tersebut akan dipergunakan untuk menjelaskan kaitan antara partisipasi penyusunan anggaran $(\mathrm{X})$ dengan kinerja aparat pemerintah daerah $(\mathrm{Y})$.

Jika uji asumsi yang disyaratkan dan uji kelayakan model tersebut terpenuhi maka analisis dapat ditunjukkan pada analisis regresi. Maksud uji asumsi tersebut jika pengujian yang dilakukan dan dapat terpenuhi maka model tersebut layak untuk digunakan.

Analisis Koefisien Determinasi $\left(\mathbf{R}^{2}\right)$

Tabel 3

Hasil Analisis Koefisien Determinasi Model Summary ${ }^{b}$

\begin{tabular}{|l|c|c|c|c|}
\hline Model & $\mathrm{R}$ & $\mathrm{R}$ Square & Adjusted R Square & $\begin{array}{c}\text { Std. Error of the } \\
\text { Estimate }\end{array}$ \\
\hline 1 & $.819^{\mathrm{a}}$ & .671 & .630 & .49120 \\
\hline
\end{tabular}

Dari tabel 3 di atas diperoleh Nilai $R$ (Korelasi) sebesar 0,819 atau $81,9 \%$, ini menunjukkan bahwa tedapat hubungan antara partisipasi penyusunan anggaran dengan kinerja aparat pemerintah daerah.

Dari hasil perhitungan regresi dapat diketahui bahwa koefisien determinasi (Adjusted $\mathrm{R}^{2}$ ) yang diperoleh sebesar 0,630 (63\%). Hal ini berarti bahwa variabel bebas yaitu partisipasi penyusunan anggaran $(X)$ pada model dapat diterangkan oleh variabel terikat yaitu kinerja aparat pemerintah daerah (Y), sedangkan 37\% dipengaruhi oleh variabel lain di luar penelitian ini, yang tidak diujikan pada penelitian ini.
Hasil pengujian statistik dengan menggunakan Statiscal Product and Service Solution (SPSS) Versi.21 dapat terlihat bahwa variabel bebas mempengaruh variabel terikat. masing-masing variabel dijelaskan sebagai berikut:

Dalam penelitian ini menunjukkan pengaruh partisipasi penyusunan anggaran adalah positif dan signifikan. Koefisien regresi partisipasi penyusunan anggaran sebesar 0,819 dan signifikan sebesar 0,004, karena nilai $\mathrm{t}$ hitung $>\mathrm{t}$ tabel $(4,041>1,860)$. Apabila dilihat dari nilai signifikannya yang kurang dari 0,05, ini berarti variabel partisipasi penyusunan anggaran berpengaruh signifikan 
terhadap kinerja aparat pemerintah daerah. Berdasarkan perhitungan hasil persamaan regresi sesuai dengan rumus yang ditentukan menghasilkan nilai sebesar 0,819 terlihat bahwa koefisien variabel partisipasi penyusunan anggaran adalah positif, ini berarti bahwa $\mathrm{H}_{1}$ diterima, artinya bahwa pengaruh partisipasi penyusunan anggaran berpengaruh signifikan terhadap kinerja aparat pemerintah daerah.

\section{SIMPULAN}

Berdasarkan penelitian yang teah dilakukan di DPPKAD Kota Palopo untuk mengetahui pengaruh partisipasi penyusunan anggaran terhadap kinerja aparat pemerintah daerah dengan menggunakan analisis regresi linear sederhana, peneliti dapat menarik kesimpulan sebagai berikut:

Dari hasil uji t diperoleh $t_{\text {hitung }}$ sebesar 4,041 > t tabel sebesar 1,860 sehingga $H_{0}$ ditolak dan $\mathrm{H}_{1}$ diterima. Artinya dengan kisaran sebesar 0,819 atau $81,9 \%$, hubungan linear antara partisipasi penyusunan anggaran terhadap kinerja aparat pemerintah daerah signifikan.

Dari hasil persamaan regresi sederhana, maka diperoleh nilai koefisien variabel independen sebesar 0,819 dapat diartikan jika variabel bebas dengan model diasumsikan setiap kenaikan satu milyar, maka rata-rata variabel diluar model tetap akan mempengaruhi kinerja aparat pemerintah daerah sebesar 0,819 . Dengan ini menunjukkan hubungan variabel pengaruh positif antara variabel dependen (kinerja aparat pemerintah daerah).dengan variabel independen (partisipasi penyusunan anggaran).

Dari hasil perhitungan koefisien determinasi (Adjusted $\mathrm{R}^{2}$ ) yang diperoleh sebesar 0,630 (63\%). Hal ini berarti $63 \%$ variasi variabel bebas yaitu partisipasi penyusunan anggaran $(X)$ pada model dapat diterangkan oleh variabel terikat yaitu kinerja aparat pemerintah daerah (Y), sedangkan $37 \%$ dipengaruhi oleh variabel lain di luar penelitian ini, yang tidak diujikan pada penelitian ini.

\section{SARAN}

Berdasarkan hasil penelitian di atas maka penulis dapat mengemukakan beberapa saran, yaitu sebagai berikut:

1. Berdasarkan penelitian di atas partisipasi penyusunan anggaran berpengaruh terhadap kinerja aparat pemerintah daerah, oleh karena itu, DPPKAD Kota Palopo harus lebih memperhatikan bahwa dalam berpartisipasi untuk penyusunan anggaran lebih mempertimbangkan kinerjanya.

2. Disarankan kepada peneliti selanjutnya, agar melanjutkan penelitian ini lebih memperbanyak lagi populasi dan sampelnya.

\section{DAFTAR PUSTAKA}

Arif, Bahtiar. 2002. Akuntansi Pemerintahan. Jakarta : Salemba Empat. Edisi Pertama.

Bangun, Andrias. 2009. Pengaruh Partisipasi Dalam Penyusunan Anggaran, 
Kejelasan Sasaran Anggaran Dan Struktur Desentralisasi Terhadap Kinerja Manajerial SKPD Dengan Pengawasan Internal Sebagai Variabel Pemoderasi. Tesis. Medan : Fakultas Ekonomi Universitas Hasanuddin Makassar. Diakses Tanggal 2 Februari 2014.

Fibrianti, Diana. 2013. Pengaruh Partisipasi Anggaran, Desentralisasi, Komitmen Organisasi, Dan Ketidakpastian Lingkungan Terhadap Kinerja Manajerial Pada Pemerintahan Kota Surabaya. Jurnal IImu dan Riset Akuntansi. (Online), Vol.1, No.1. Diakses Tanggal 18 Januari 2014.

Husin, Rakib. 2013. Pengaruh Partisipasi Anggaran Terhadap Kinerja Pimpinan dengan Desentralisasi, Budget Goal Commitment dan Job-Relevant Infortamtian Sebagai Variabel Moderating. Skripsi. Brawijaya : Fakultas Ekonomi Universitas Brawijaya. Diakses Tanggal 2 Februari 2014.

Bagus, Ida. 2010. Penganggaran Perusahaan: Graha Ilmu. Yogyakarta. Edisi pertama.

Bastian, Indra. 2006. Akuntansi Sektor Pablik: Erlangga. Yogyakarta.

Keputusan Peraturan Menteri Dalam Negri Nomor 13 tahun 2006 tentang Pedoman Dalam Rancangan Anggaran Pendapatan Dan Belanja Daerah.

Matolla, Ridwan. 2011. Pengaruh Partisipasi Anggaran Terhadap Kinerja Dengan Locus Of Control Sebagai Variabel Moderating. Skripsi. Makassar : Fakultas Ekonomi Universitas Hasanuddin. Diakses Tanggal 18 Januari 2014.

Mediaty. 2010. Pengaruh Partisipasi Penyusunan Anggaran, Dan Gaya Kepemimpinan Terhadap Kinerja Aparatur Pemerintah Daerah Provinsi
Sulawesi Selatan. Skripsi. Makassar : Fakultas Ekonomi Universitas Hasanuddin Makassar. Diakses Tanggal 18 Januari 2014.

Nafarin, M. 2007. Penganggaran Perusahaan: Salemba Empat Banjarmasin. Edisi tiga

Munawar, 2006. Pengaruh Ka rakteristik Tujuan Anggaran Terhadap Perilaku, Sikap dan Kinerja Aparat Pemerintah Daerah di Kabupaten Kupang. Tesis. Diakses Tanggal 18 Januari 2014.

Nor, Wahyudian. 2007. Desentralisasi dan Gaya Kepemimpinan Sebagai Variabel Moderating Dalam Hubungan Antara Partisipasi Penyusunan Anggaran dan Kinerja Manajerial. Simposium Nasional Akuntansi $X$, Makassar. Diakses Tanggal 18 Januari 2014.

Puspaningsih, Abriyani. 2002. Pengaruh Partisipasi Dalam Penyusunan Anggaran Terhadap Kepuasan Kerja Dan Kinerja Manajer. JAAI. (Online), Vol.6, No.2. Diakses Tanggal 18 Januari 2014.

Sarjito, Bambang. 2007. Pengaruh Partisipasi Penyusunan Anggaran Terhadap Kinerja Aparat Pemerintah Daerah : Budaya organisasi dan Komitmen Organisasi sebagai Variabel Moderating. Simposium Nasional Akuntansi X Unhas Makassar

Silmian. 2013. Pengaruh Partisipasi Penyusunan Anggaran Terhadap Kinerja Manajerial Aparatur Pemerintah Dengan Motivasi Kerja Dan Internal Locus Of Control. Tesis. Padang : Fakultas Ekonomi Universitas Negeri Padang.

Sinuraya, Chandra. 2009. Pengaruh Partisipasi Penyusunan Anggaran Dan Komitmen Organisasi Terhadap Kepuasan Kerja dan Kinerja Karyawan. Jurnal Akuntansi. (Online), Vol.1, No.1. Diakses Tanggal 18 Januari 2014. 
Siskawati, Vidya. 2004. Pengaruh Partisipasi Anggaran Terhadap Kepuasan Kerja dan Kinerja Pemda, Skripsi : Universitas Bung Hatta Padang. Diakses Tanggal 28 Januarl 2014.

Sumamo. 2005. Pengaruh Komitmen Organisasi dan gaya Kepemimpinan terhadap Hubungan antara Partisipasi Anggaran dan Kinerja Manajerial: Simposium Nasional VIII, Solo. Diakses Tanggal 16 januari 2014. 